\title{
A systematic approach to modeling sustainable production and economic activities of transport organizations
}

\author{
Nikita Drozdov ${ }^{1}$,Elena Kuzina ${ }^{2}$, Marina Vasilenko ${ }^{3, *}$, Julia Tagiltseva ${ }^{4}$, Vyacheslav Galkin ${ }^{2}$, \\ Vladimir Prokopchuk ${ }^{2}$, Natalia Korenyakina ${ }^{5}$, and Anastasia Laponogova ${ }^{6}$ \\ ${ }^{1}$ Technological institute (branch) of Don state technical university in Azov,Promyshlennaya st.,1, \\ 346780, Azov, Russia \\ ${ }^{2}$ Russian University of Transport. RUT - MIIT, Obraztsova, 9, building 9, 127994, Moscow, Russia \\ ${ }^{3}$ Rostov State Medical University, RostGMU of the Ministry of Health of Russia Nakhchivansky \\ lane, 29, 344000, Rostov-on-Don, Russia \\ ${ }^{4}$ Russian customs Academy Rostov branch, 20 Budennovsky Ave., 344002, Rostov-on-Don, Russia \\ ${ }^{5}$ Rostov State University of Railway Transport (RSUPS), pl. Rostov Rifle Regiment of the People's \\ Republic of Tatarstan Opolcheniya, 2, 344038, Rostov-on-Don, Russia \\ ${ }^{6}$ Rostov State Economic University. RGEU (RINH), Bolshaya Sadovaya St, 65, 344000, Rostov-on- \\ Don, Russia
}

\begin{abstract}
Business decisions, transport organizations are guide by the principles of maximizing economic efficiency, reducing costs, and corporate social responsibility. Nevertheless, in the production and economic activities of transport enterprises, there are non-productive costs associated with their environmental activities: payment for excess and permissible pollution, costs of eliminating the consequences, accumulated damage, etc. To minimize this type of costs, it is propose to build a model of the activity of transport organizations from the standpoint of a systematic approach, which includes production processes, elements of production processes, management functions, and components of transport impact and aspects of corporate and social liability. The developed model can find its application in planning organizational and technical measures during their formation. The article presents information on unproductive excess costs of the transport industry of the Russian Federation in the period 2013-2016 y.o. The components of transport impact in transport organizations are considered. A model of production and economic activity of transport organizations from the standpoint of a systematic approach is proposed.
\end{abstract}

\section{Introduction}

To context of the global economic crisis, the issue of maintaining the save position of enterprises in the market comes to the fore. Transport organizations have several tools for influence the organizational environment in order to maximize the economic efficiency of production activities in changing conditions. One of these tools is cost planning, which,

\footnotetext{
*Corresponding author: margo2026@yandex.ru
} 
taking into account the specifics of transport organizations, have a number of unproductive components, such as payment for environmental pollution, costs of eliminating the consequences of accidents and disasters, payment of legal costs and the work of lawyers in cases related to environmental pollution. The authors of the article attribute such costs to unproductive excess costs of transport enterprises.

To the figurel provides information on the unproductive excess costs of transport organizations that create a negative business reputation.

Systems approach is a tool with which you can consider the object under study as an integral system consisting of interconnected elements. Modeling the activities of transport organizations using a systematic approach is necessary to study the mechanism for making economic decisions, taking into account institutional factors, including economic (production processes and their elements), environmental (components of transport impact), social (aspects of corporate and social responsibility of enterprises).

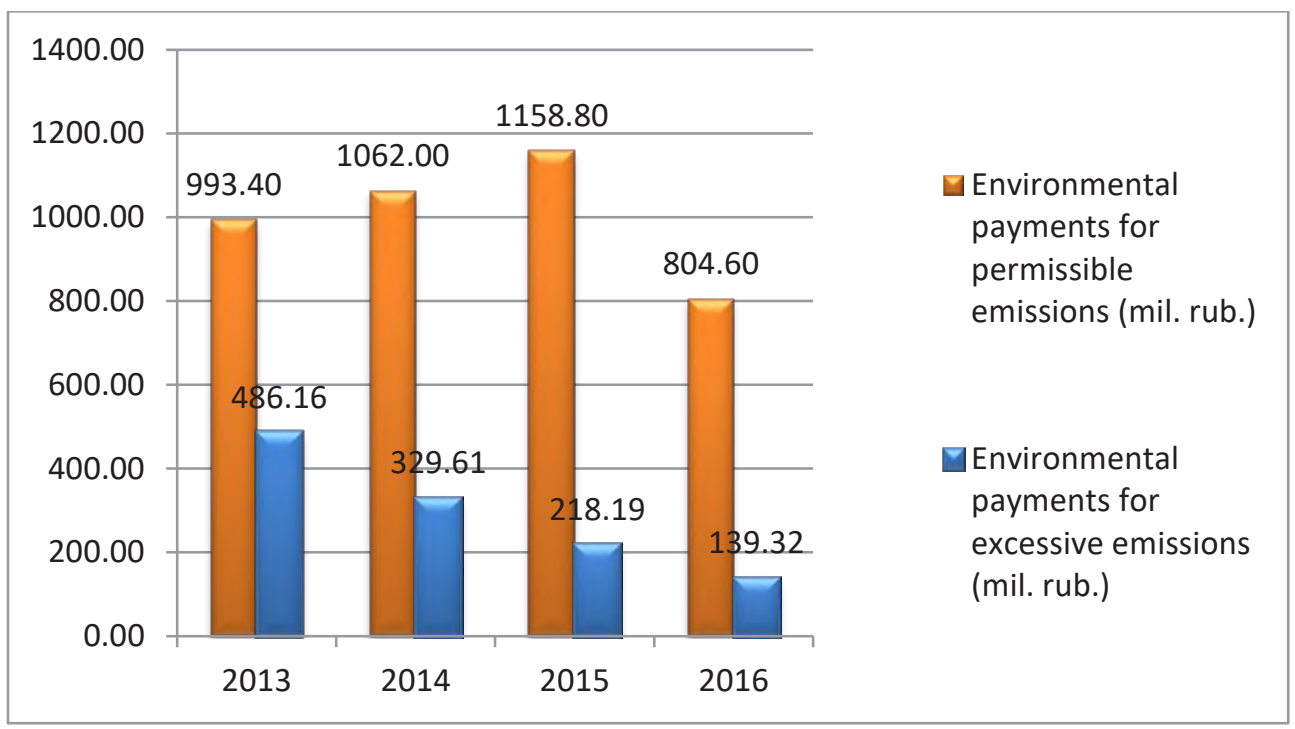

Fig. 1. Unproductive excess costs of enterprises of the transport industry of the Russian Federation in the 2013-2016 (mil. Rub.)

Thus, there is has to develop a model of production and economic activity of transport enterprises to reduce operating costs when making economic decisions. This makes the topic of the article relevant.

The aim of the study is to develop a model of production and economic activities of transport organizations using a systematic approach.

\section{Methods}

A number of works by domestic and foreign researchers are devoted to the modeling of production and economic activities of transport organizations. Assuming the materials studied, we can note that much attention in modeling the activities of transport enterprises is pay to the process approach and analysis of business processes [1-4].

A systematic approach to the study of the production and economic activity of economic entities, including transport organizations, is consider as a tool for the study of complex systems with many inputs, many outputs and many interconnected components [5-8]. It can be note the similarity of the process and system approaches in what components of production 
and economic activity are consider in both approaches: inputs and outputs, production processes of the enterprise and their components.

The authors of the article use a systematic approach, first, to model the interaction of the components of the work of a transport company: production processes, their elements, management functions and other components that affect economic activity and lead to unproductive costs.

Methods for modeling production and economic activities are widely covered in the works [9-12]. The authors of the article chose a morphological model as a model as it clearly reflects, from the standpoint of a systematic approach, the process of influence of individual elements of the production system of a transport enterprise on the economic decisions and unproductive costs.

\section{Results}

The main production process of transport organizations is transportation, which includes subprocesses: unloading, loading, movement. The main sub-processes are support by the coordinated work of the rest of the departments that carry out supporting processes, such as:

- Scientific research.

- Repair.

- Transportation.

- Storage.

- Disposal.

- Construction.

- Service, etc.

The elements of production processes are: work force, raw materials, materials, work (services), components, information, investments, fixed assets, intangible assets, corporate interest, etc.

Management functions appear in the morphological model as the types of management activities based on cooperation in management M. Mescon identifies four main management functions: planning, organization, motivation and control. Inside the main functions, other management functions can be distinguishes, such as regulation, coordination, forecasting, conclusion of transactions, accounting, regulation, etc. [13].

The above triad can be clearly shown in the form of a morphological model - a Zwicky cube each face of which reflects production processes (array A), elements of production processes (array B), management functions (array C).. Figure 1 shows this model.

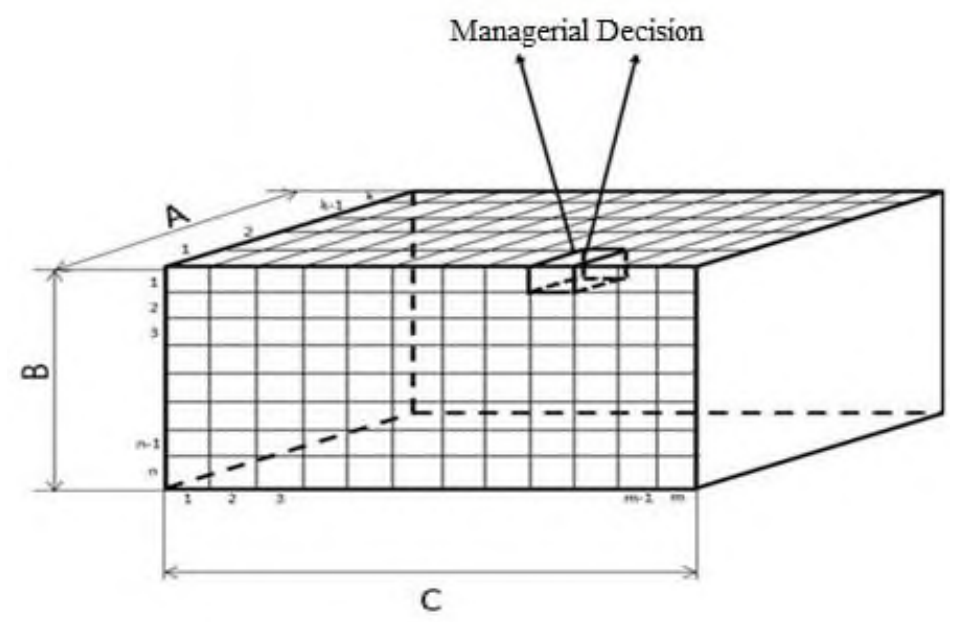


Fig. 2. Morphological model of making managerial decisions at transport enterprises

Ways to reduce exploitative costs in the framework of the planning function need to look in the dyad "Production process - Production element". Planning as the main management function can involve other management functions.

Regarding the dyad "Production process - Element of the production process", the third component of the emergence of excess non-productive costs is singled out - the component of transport impact. It is understand as such a set of effects from production processes, which leads or is capable of leading to the emergence of non-productive costs, normative or overnormative [14]. These include public, ecological, economic, and reputational. Table 1 provides detailed information on the impact components of transport enterprises.

Table 1. Components of transport impact in transport organizations

\begin{tabular}{|c|c|c|}
\hline $\begin{array}{l}\text { Group of transport } \\
\text { impact } \\
\text { components }\end{array}$ & $\begin{array}{l}\text { The name of the transport impact } \\
\text { component }\end{array}$ & $\begin{array}{l}\text { Demonstration component of } \\
\text { transport impact }\end{array}$ \\
\hline \multirow{3}{*}{ Public } & $\begin{array}{l}\text { Business activity in the territories } \\
\text { adjacent to the road landfill } \\
\text { (transport infrastructure zone) }\end{array}$ & $\begin{array}{l}\text { Increase - positive } \\
\text { Decrease - negative }\end{array}$ \\
\hline & Working conditions of employees & $\begin{array}{l}\text { Improvement }- \text { positive } \\
\text { Deterioration - negative }\end{array}$ \\
\hline & $\begin{array}{l}\text { Living conditions of people in the } \\
\text { territories adjacent to the road } \\
\text { landfill (transport infrastructure } \\
\text { zone) }\end{array}$ & $\begin{array}{l}\text { Improvement - positive } \\
\text { Deterioration - negative }\end{array}$ \\
\hline \multirow{6}{*}{ Ecological } & $\begin{array}{l}\text { Impact on environmental } \\
\text { components }\end{array}$ & $\begin{array}{l}\text { Increase - positive } \\
\text { Decrease - negative }\end{array}$ \\
\hline & Noise impact & $\begin{array}{l}\text { Increase - positive } \\
\text { Decrease - negative }\end{array}$ \\
\hline & Vibration impact & $\begin{array}{l}\text { Increase - positive } \\
\text { Decrease - negative }\end{array}$ \\
\hline & Electromagnetic impact & $\begin{array}{l}\text { Increase - positive } \\
\text { Decrease - negative }\end{array}$ \\
\hline & Restoring territories & $\begin{array}{l}\text { Increase - positive } \\
\text { Decrease - negative }\end{array}$ \\
\hline & Agricultural land area & $\begin{array}{l}\text { Increase - positive } \\
\text { Decrease - negative }\end{array}$ \\
\hline \multirow{4}{*}{ Reputational } & Impact on goodwill & $\begin{array}{l}\text { Increase - positive } \\
\text { Decrease - negative }\end{array}$ \\
\hline & Number of clients & $\begin{array}{l}\text { Increase - positive } \\
\text { Decrease - negative }\end{array}$ \\
\hline & Market share & $\begin{array}{l}\text { Increase - positive } \\
\text { Decrease - negative }\end{array}$ \\
\hline & Share price & $\begin{array}{l}\text { Increase - positive } \\
\text { Decrease - negative }\end{array}$ \\
\hline
\end{tabular}




\begin{tabular}{|c|c|c|}
\hline & Sales growth rates & $\begin{array}{l}\text { Increase - positive } \\
\text { Decrease - negative }\end{array}$ \\
\hline
\end{tabular}

Thus, the occurrence of unproductive costs can be represent in the form of a morphological model relative to the triad "production process - production process element - transport impact component" (array D Figure 2 shows this triad.

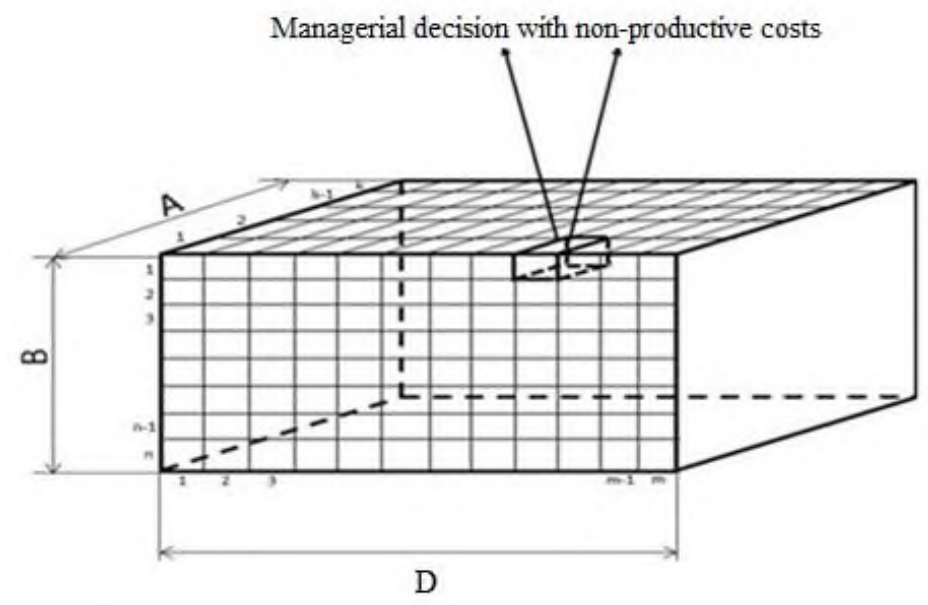

Fig. 3. Making economic decisions by transport organizations that lead to the emergence of nonproductive costs

The principles of managing the activities of a transport organization fit into the scheme of ensuring corporate social responsibility. The practice of introducing corporate social responsibility programs assumes that an enterprise accepts responsibility for its impact on society, is ready to account for its actions, and keep records of them. Devyatlovsky D.N. and Pozdnyakova M.O. believe that "the presence of corporate social responsibility (or social responsibility of business) as a public phenomenon indicates an increase in the level of human development" [15]. Kivarina M.V. believes that the development and strengthening of Russian business "will depend on how timely and adequate it will perceive the basic principles of corporate and social responsibility. Only in this case he will be able to become the engine of positive changes in socially significant spheres of society, create and maintain decent working conditions for the personnel employed at his enterprises "[16].

The social responsibility of business today is economically profitable for enterprises from the standpoint of development. Socially responsible business is position as an efficient business [17], and the absence of corporate social responsibility programs automatically creates the basis for the application of penalties to such organizations. The state authorities of the Russian Federation are moving towards a tougher environmental policy [18-19], therefore, we can expect a further increase in penalties for violations of the principles of corporate social responsibility, including environmental and social negative externalities.

Motivation of the transport organization from the perspective of corporate social responsibility can be consider in several aspects, such as:

- Saving and improving the business reputation of the transport organization (aspect - 1).

- Ensuring sustainable development of territories (aspect - 2).

- Ensuring the social development of personnel of organizations (aspect - 3).

- Improvement of the ecological situation (environmental protection) (aspect - 4).

- Increased non-transport effect (aspect - 5).

- Resource saving (aspect - 6). 
Figure 3 depicts a morphological model for making economic decisions, taking into account transport impact and corporate social responsibility.

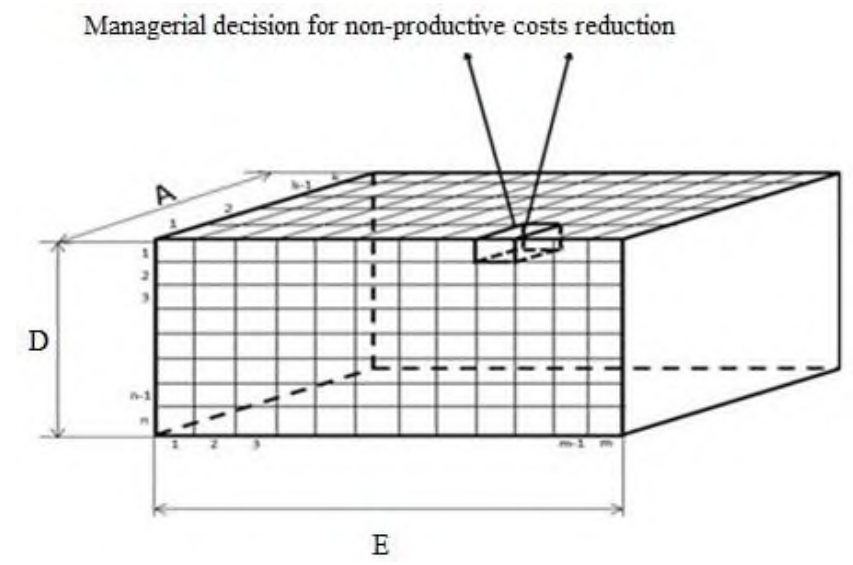

Fig. 4. Model of making economic decisions aimed at reducing non-productive costs

The generated economic solutions will be focus on reducing unproductive excess costs and increasing corporate social responsibility. Thus, based on the constructed morphological models, it is possible to propose a model of the activity of a transport organization. Such a model is show in Figure 4. 


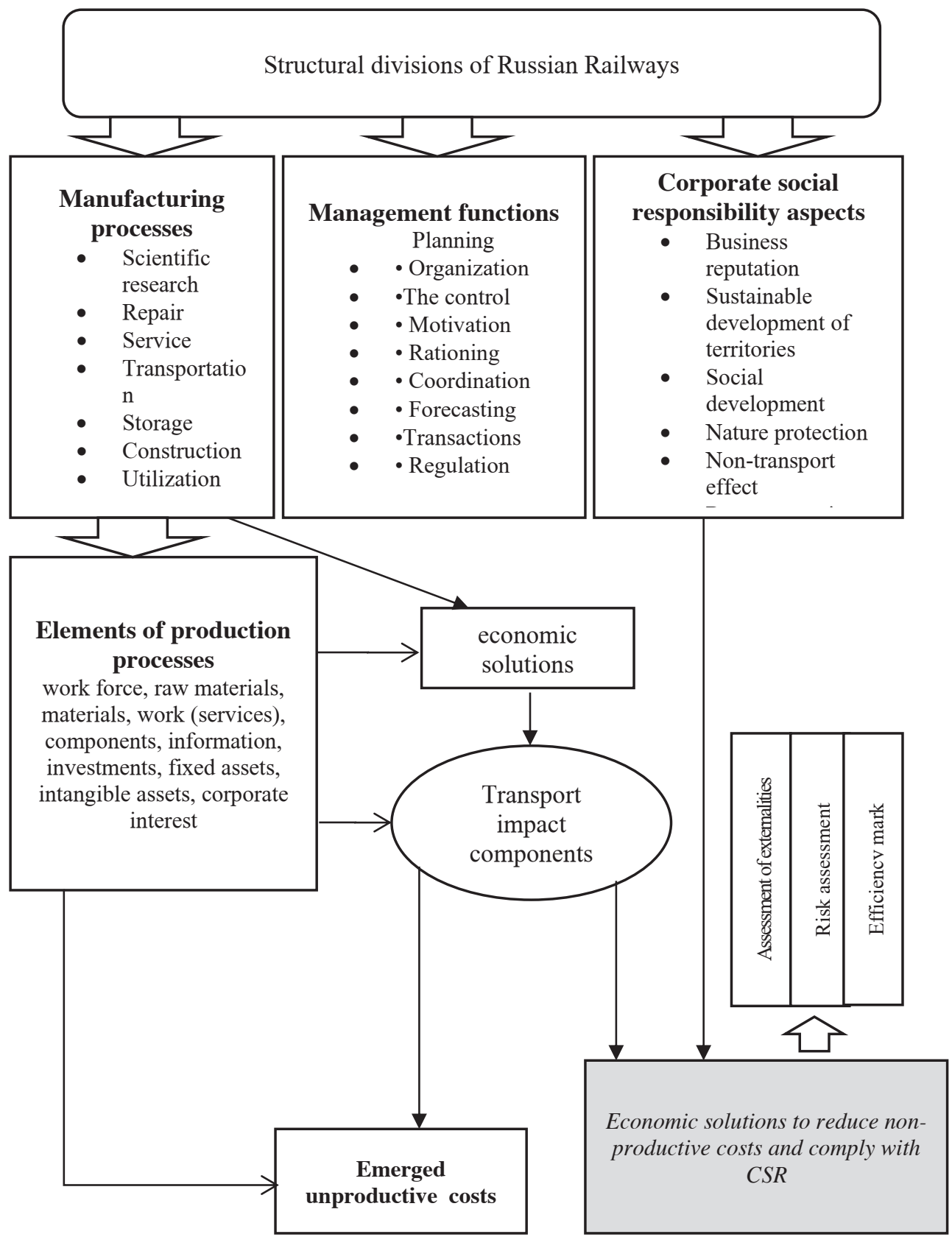

Fig. 5. Model of production and economic activity of transport organizations from the standpoint of a systematic approach

Thus, the economic decisions taken by transport enterprises that ensure the reduction of non-productive costs and adherence to the principles of corporate social responsibility, according to the model shown in the figure, are taken to eliminate non-productive costs, based on the identified components of the transport impact in terms of corporate social responsibility. The components of the transport impact that arise from the economic decisions taken by transport enterprises, in turn, contain three elements: the production process, an element of the production process, and the management function. 


\section{Discussion}

The research results can be used to develop a method for planning organizational and technical measures in transport organizations. At present, the planning of the activities of economic units is carrier out according to the elements of the costs of each unit [20]. The approach proposed by the authors will make it possible to take into account previously unaccounted for unproductive costs in planning costs at transport enterprises and take measures to reduce or minimize them. The orientation of all economic decisions to reduce non-productive costs will increase the off-transport effects due to the orientation of the planned organizational and technical measures to fulfill the principles of corporate social responsibility.

\section{Conclusion}

Thus, the article developed a model of production and economic activity of a transport company using a systematic approach. The elements of the production system, such as production processes, elements of production processes, management functions, are considered, the components of transport impact and aspects of corporate social responsibility are identified and described.

\section{References}

1. N. V. Smirnova, Vestnik of MSTU, 2, 268 (2008)

2. L. F. Popova, Perm University Herald. Economy, 3, 453 (2017)

3. I. N. Sycheva, E. S. Permyakova, Economy and business: theory and practice, 4, 246 (2018)

4. T. V. Zyrianova, Y. S. Tarnovskaya, International Accounting, 44, 15 (2012)

5. A. Kh. Mambetov, Z. A. Erzhibova, Terra Economicus, 2-3, 244 (2009)

6. A. G. Stepanov, S.G. Semin, Information and Control Systems, 1, 92 (2015)

7. V. V. Zyabrikov, Problems of modern economics, 3, 93 (2016)

8. A. A. Zubarev, H. K. Skvortsova, Society: Politics, Economics, Law 11, 43 (2016)

9. V. E. Pinaev, Moscow University Economics Bulletin, 3, 54 (2013)

10. S. S. Nazarenko, News of the Tula state university. Economic and legal sciences, 1, 159 (2012)

11. S. B. Kuznetsov, Vestnik of ChelGU, 16, 54 (2011)

12. A. A. Mitsel, E. B. Gribanova, Proceedings of TUSUR University, 3, 49 (2005)

13. M. A. Vasilenko, E. L. Kuzina, N. A. Drozdov, S. Sh. Magomedov, E. A. Vasilenko, E. E. Shlykov, International Scientific Conference «Social and Cultural Transformations in the Context of Modern Globalism» dedicated to the 80th anniversary of Turkayev Hassan Vakhitovich, 2585 (2020)

14. J. A. Tagilteva, E. L. Kuzina, O. A. Bortnik, E. E. Shlykov, S. Sh. Magomedov, M. A. Vasilenko, N. A. Drozdov, International Conference «Quality Management, Transport and Information Security, Information Technologies» (IT\&QM\&IS), 100 (2019) 
15. D. N. Devyatlovskiy, M. O. Pozdnyakova, Problems of the modern economy 50, 173 (2014).

16. M. V. Kivarina, Ekonomicheskiy Zhurnal, 4, 59 (2014)

17. A. S. Kostyakina, Terra Economicus, 2-3, 32 (2009)

18. L. S. Sinkov, E. I. Stepuk, A. N. Martemyanova, Mining informational and analytical bulletin, 40, 116 (2015)

19. T. O. Tagaeva, V. M. Gilmundinov, L. K. Kazantseva, Economy of region, 11, 78 (2016)

20. N. A. Drozdov, M. A. Vasilenko, J. A. Tagilteva, E. L. Kuzina, IEEE Conference of Russian Young Researchers in Electrical and Electronic Engineering (EIConRus), 1254 (2018) 